https://helda.helsinki.fi

\title{
The effect of topography on arctic-alpine aboveground biomass and NDVI patterns
}

\section{Riihimäki, Henri}

2017-04

Riihimäki , H , Heiskanen , J \& Luoto , M 2017 , ' The effect of topography on arctic-alpine aboveground biomass and NDVI patterns ' , International Journal of Applied Earth Observation and Geoinformation , vol. 56 , pp. 44-53 . https://doi.org/10.1016/j.jag.2016.11.005

http://hdl.handle.net/10138/307566

https://doi.org/10.1016/j.jag.2016.11.005

cc_by_nc_nd

acceptedVersion

Downloaded from Helda, University of Helsinki institutional repository.

This is an electronic reprint of the original article.

This reprint may differ from the original in pagination and typographic detail.

Please cite the original version. 


\title{
The effect of topography on Arctic-alpine aboveground biomass and NDVI patterns Henri Riihimäki, Janne Heiskanen \& Miska Luoto
}

\author{
Corresponding author: Henri Riihimäki, henri.riihimaki@ @elsinki.fi, +358504488561 \\ Janne Heiskanen, janne.heiskanen@ helsinki.fi \\ Miska Luoto, miska.luoto@ helsinki.fi \\ Department of Geosciences and Geography, \\ Gustaf Hällströmin katu 2a, P.O. box 64, 00014 University of Helsinki, Finland
}

International journal of applied earth observation and geoinformation

\begin{abstract}
Topography is a key factor affecting numerous environmental phenomena, including Arctic and alpine aboveground biomass (AGB) distribution.. Digital Elevation Model (DEM) is a source of topographic information which can be linked to local growing conditions. Here, we investigated the effect of DEM derived variables, namely elevation, topographic position, radiation and wetness on field measured AGB and Normalized Difference Vegetation Index (NDVI) in Fennoscandian forest-alpine tundra ecotone. Boosted regression trees were used to derive non-parametric response curves and relative influences of the explanatory variables. Elevation and potential incoming solar radiation were the most important explanatory variables for both AGB and NDVI. In the NDVI models their response curves were much smoother compared with AGB models. This might be caused by large contribution of field and shrub layer to NDVI. Furthermore, radiation and elevation had a significant interaction, showing that the highest NDVI and biomass values are found from low-elevation, high-radiation sites, typically on the south-southwest facing valley slopes. Topographic wetness had minor influence on AGB and NDVI. Topographic position had mixed, generally weak effects on AGB and NDVI, although protected topographic position seemed to be more favorable below the treeline. The explanatory power of the topographic variables, particularly elevation and radiation demonstrates that DEM-derived land surface parameters can be used for exploring biomass distribution resulting from landform control on local growing conditions.
\end{abstract}

Keywords: Normalized Difference Vegetation Index, Digital Elevation Model, DEM, Treeline, Phytomass 


\section{Introduction}

Changes have been observed in arctic and alpine areas regarding plant productivity, shrub abundance, tree line position and aboveground biomass (AGB) (Epstein et al., 2012; Myneni et al., 1997; Sturm et al., 2001). Productivity and biomass are key factors controlling many other phenomena in arctic and alpine environments, such as species richness and composition, surface albedo and frost phenomena (Blok et al., 2011; Hjort and Luoto, 2009; Virtanen et al., 2010). Spectral vegetation indices, such as the normalized difference vegetation index (NDVI), are sensitive to the amount green chlorophyll, i.e. the photosynthetically active biomass of the plants, which again is strongly related to the total aboveground biomass (Tucker, 1979; Heiskanen, 2006). NDVI can be derived from multispectral passive remote sensing data (e.g. AVHRR, Landsat), which have had global coverage since the 1970's. Because of these properties, spectral vegetation indices and especially NDVI have thus far been the most common way to model aboveground distribution over large areas to this day (Xie et al., 2008). The NDVI has been commonly used for modelling AGB in arctic and alpine areas (e.g., Barrachina et al., 2015; Johansen and Tommervik, 2014; Walker et al., 2003) and mountain birch forests (Heiskanen, 2006).

Active remote sensing methods, such as Light Detection and Ranging (LiDAR) and radar, provide also possibilities to measure AGB as they can measure vegetation height and volume directly, and are therefore closely related to aboveground biomass. LiDAR is more commonly used to model AGB distribution, also in Arctic and alpine areas (Greaves et al., 2015; Nyström et al., 2012; Tonolli et al. 2010). However, most of the LiDAR studies are local to region scale and, as of now, there aren't any global or circumpolar LiDAR data sets available. Synthetic Aperture Radar (SAR) have also been succesfully tested in High-Arctic biomass modelling (Collingwood et al., 2013), but in this study we do not inspect radar data sets any further and focus only on passive satellite remote sensing data. The continuity of the satellite-NDVI data makes it particularly interesting when aiming for example global change studies. Therefore, we think its highly important to inspect these relationships between satellite-NDVI, a dynamic variable, and a digital elevation model, a rather stable data source, which can be utilized for example to downscale satellite data in the future.

Topography controls local growing conditions in many ways, it effects to local climate by altitude and exposure of the area, but also to nutrient and soil moisture conditions. As a result AGB is unevenly distributed in topographically complex landscapes, where it's hard to interpret coarse resolution NDVI data (e.g. MODIS, AVHRR), as a single pixel can include various types of environments (Jiang et al., 2006). Thus, it is necessary to examine the influence of local topography to AGB, but also to its commonly used proxy, the NDVI. 
Digital Elevation Model (DEM) is a great source of topographic information which can be linked to microclimate, hydrology, geomorphology (Dobrowski, 2011; Franklin, 1995; Moore et al., 1991) and eventually to vegetation properties such as productivity, species richness and biomass (Bruun et al., 2006; Fisk et al., 1998; Walker et al., 1993). These relatively static variables (i.e. topography changes slowly) provide the basis in which more dynamic processes such as climate change and changes in AGB occur. In the landscape and local scale $\left(<1 \mathrm{~km}^{2}\right)$, climate is controlled by altitude, aspect and slope, which affects to solar insolation (Böhner and Antonić, 2009). The local variation in climate mostly depends on 1) elevation (adiabatic lapse rate), 2) received solar radiation and 3) cold air pooling, which are controlled by local topography. In the northern hemisphere, south facing slopes receive more thermal radiation and have longer growing season compared to north facing slopes. Uneven distribution of the thermal radiation creates a mosaic of thermally different microhabitats in topographically complex areas (Dobrowski, 2011; Dobrowski et al., 2009; Scherrer and Körner, 2011).

The topographic position affects growing conditions through various indirect effects (Billings and Mooney, 1968; Broll et al., 2007). Cold air pooling and seasonal cold air spells in negative topographic positions (i.e. positions below their surrounding terrain) can damage plants, especially early in the growing season (Körner, 2012; Larcher et al., 2010). Land formations in part control soil development and properties, which affect to soil moisture distribution and nutrient availability (Stewart et al., 2014). Flat and exposed snow-free areas are prone to damages caused by wind and extreme temperatures during winter (Billings and Mooney, 1968; Larcher et al., 2010). Snow is accumulated to concave, protected land forms, while exposed areas have thin or no snow cover. In areas where the snowpack is the thickest, the protection effect of snow might turn out to be negative if the start of the growing season is significantly delayed. As water (meltwater or rain) moves towards downslope, soil moisture, amount of organic matter, nitrogen and other nutrients and total carbon usually increases when moving down in the topographic gradient (Fisk et al., 1998; Stewart et al., 2014). This in general supports plant biomass production (Berdanier and Klein, 2011; Chapin et al., 1988; Fisk et al., 1998), however, at the bottom part of the slope excessive water might saturate the top soil, which may hinder productivity and biomass accumulation.

The first aim of this study was to test whether land surface parameters (LSPs) which are linked to growing conditions can explain AGB and NDVI distribution. To do this, two topographic variables were selected which are closely related to local climate (elevation, potential incoming solar radiation) and two which are related to soil moisture and nutrient distribution (topographic position index, topographic wetness index). Modelling was performed with boosted regression trees. Secondly, as NDVI is the most common spectral vegetation index used for high-latitude AGB mapping, it was tested whether the responses are similar compared to field measured AGB. 


\section{Material and methods}

\subsection{Study area}

The study area is located in northwestern Finland, $69^{\circ} \mathrm{N}, 21^{\circ} \mathrm{E}$ (Fig. 1). Sampling was conducted around six fells and in one gently sloping site. Western part of the study area is mountain tundra, while eastern part of the area is considered as pure arctic (Virtanen et al., 2016). The mean sum of daily temperatures exceeding $+3{ }^{\circ} \mathrm{C}$ was 678 growing degree days and the mean precipitation was $501 \mathrm{~mm}$ per year in 1985-2008 at $480 \mathrm{~m}$. a.s.l. (Virtanen et al., 2010). Valleys and lower slopes of the fells are covered by mountain birch (Betula pubescens ssp. czerepanovii). The treeline is at maximum $740 \mathrm{~m}$. a.s.l. but much lower in many parts of the area. Main shrub species are Betula nana, Salix spp. and Juniperus communis ssp. nana (syn. ssp. alpina). The most important dwarf shrub is Empetrum nigrum ssp. hermaphroditum, which characterizes field layer of the most forest types (Mikkola and Sepponen, 1986). Furthermore, Empetrum-heaths are the most common vegetation type above the treeline (Eurola et al., 2003). Cladonia spp. lichens are common throughout the study area but heavily consumed by the semi-domestic reindeer (Käyhkö and Pellikka, 1994).

\subsection{Field data}

During peak growing season of 2008-2011, a total of 359 biomass reference plots (6 m radius) were measured in transects located between 461-1029 m. a.s.l. (Fig. 1). In each transect, a plot was placed every $20 \mathrm{~m}$ interval in vertical distance. Four $20 \mathrm{~cm} \times 20 \mathrm{~cm}$ clip-harvest samples were systematically taken $5 \mathrm{~m}$ from plot center to each cardinal direction. In the fell tops, only two samples were taken. The location was recorded with Garmin eTrexVenture GPS-receiver (location accuracy $\sim 15 \mathrm{~m}$ ). Due the error margin, we left the GPS logging for at least a minute to get an accurate position. Furthermore, we tested the analyses with both point only and focal mean or median (i.e. extracting raster values from $30 \times 30 \mathrm{~m}$ window) raster data to see whether there are large differences in the results. 


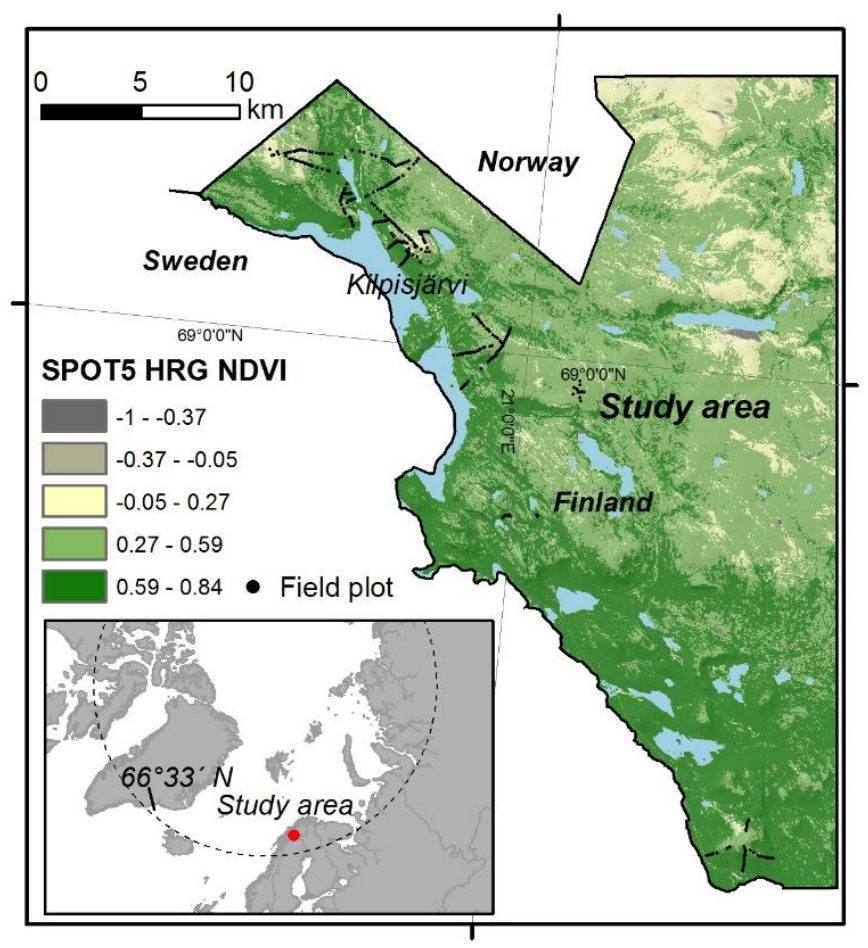

Figure 1. The location of the study area and field plots with NDVI based on SPOT 5 HRG image.

Biomass samples were separated in three functional groups (vascular plants, lichens and mosses) and dried for 48 hours in $65{ }^{\circ} \mathrm{C}$ to obtain the dry weight. Below the treeline, the number of stems and tree genets were counted. Sample trees were selected systematically by taking the first seven trees in clock ward direction from the bottom point of the plot. For each sample tree, the median stem stump diameter was measured $(D ; \mathrm{cm})$. Biomass was estimated by using local allometric model (Järvinen and Partanen, 2008):

$$
\text { biomass }=307.9 \times D^{2.756}
$$

The tree biomass of the plot was then computed by multiplying the average biomass of the sampled stems and total number of stems within the plot. Finally, the total aboveground biomass (hereafter AGB) was calculated as a sum of tree, vascular plant, moss and lichen biomasses. AGB in the study plots varied from 0 to $5647 \mathrm{~g}$ $\mathrm{m}^{-2}$ with a median of $448.8 \mathrm{~g} \mathrm{~m}^{-2}$. Most of the AGB was in vascular plants and trees, while mosses and lichens had only minor contribution (Appendix 1). 


\subsection{Digital Elevation Model and land surface parameters}

The photogrammetric digital elevation model (DEM) at $10 \mathrm{~m}$ resolution was provided by National Land Survey of Finland (NLS, 2016a, 2016b). All the land surface parameters were calculated in SAGA GIS software, v. 2.1.2. ${ }^{1}$. Default settings were used in the algorithms, if not stated otherwise. Yearly potential incoming solar radiation was calculated at hourly interval for the DEM using the Potential Incoming Solar Radiation module (Böhner and Antonić, 2009). The algorithm calculates both direct and diffuse radiation, as modified by the topography, assuming clear sky conditions. Latitude was set to $69^{\circ}$ and a sky view factor adjustment layer was used to account the obstruction of the overlying sky hemisphere by the surrounding landscape. The layers were then summed to obtain total insolation. Topographic position index (TPI) was calculated with the Topographic Position Index -module (Weiss, 2001; Wilson and Gallant, 2000). TPI is the difference to the mean elevation at a given radius (Guisan et al., 1999). $50 \mathrm{~m}$ and $300 \mathrm{~m}$ radius were used for local and landscape scale variation of the topographic position, respectively. Topographic wetness was estimated with SAGA Wetness Index (SWI) (Böhner and Selige, 2006). Before calculating the catchment area and slope for the wetness index, the DEM was preprocessed by filling sinks (Wang and Liu, 2006). SWI algorithm was preferred over the normal topographic wetness index (Moore et al., 1993), as it takes into account small differences in altitude (or DEM errors), which might cause artifacts. SWI algorithm modifies the catchment area (SCAM) of each grid cell iteratively in dependence of neighboring maximum values, using a slope-dependent equation unless the results remain unchanged by additional iterations (Böhner and Selige, 2006). SWI is calculated with the $\mathrm{SCA}_{\mathrm{M}}$ and the basic topographic wetness index formula, where $\tan (\beta)$ is the local slope:

$$
S W I=\ln \left(\frac{S C A_{M}}{\tan (\beta)}\right)
$$

\subsection{Satellite data}

A cloud-free, orthorectified 10 meter resolution SPOT 5 HRG (High Resolution Geometric) image was downloaded from SACCESS service ${ }^{2}$. The image was taken during the peak biomass season, $14^{\text {th }}$ of August, 2012. The image was projected to EUREF FIN35TM coordinate system with cubic convolution resampling, to match it with the DEM. Furthermore, a dark object subtraction (DOS) atmospheric correction was performed (Song et al., 2001). NDVI was then calculated from the corrected image (Tucker, 1979):

$$
N D V I=\frac{\rho N I R-\rho \operatorname{Red}}{\rho N I R+\rho \operatorname{Red}}
$$

\footnotetext{
${ }^{1} \mathrm{http}: / /$ www.saga-gis.org/en/index.html

${ }^{2}$ https://saccess.lantmateriet.se/portal/saccess_se.htm
} 
where $\rho$ Red and $\rho$ NIR and are reflectance in red and NIR spectral bands, respectively. Finally, NDVI values were extracted from the field plot center coordinates.

\subsection{Statistical analysis}

First, a linear regression model was used to examine the relationship between AGB and NDVI. Then a modified logarithmic transformation was used for AGB to account for the non-normal distribution and zero values of the data (McCune et al., 2002):

$$
y=\log _{10}(x+a)-b
$$

where $y$ is the transformed AGB, $x$ is the measured AGB, and $a$ and $b$ are integer and decimal parts of the logarithm of the smallest non-zero AGB $\left(0.0125 \mathrm{~g} \mathrm{~m}^{-2}\right)$, respectively.

Next, boosted regression trees (BRT) were used to obtain non-parametric response curves for each LSP and to inspect their relative influence on AGB and NDVI. BRT utilizes two algorithms, boosting and regression trees (Elith et al., 2008). Boosting is a numerical optimization technique for minimizing the loss function where each new tree, in turn, best reduces the loss function (Friedman, 2001). In the first tree all the explanatory variables are incorporated and a regression tree is created which maximally reduces the loss function. Each subsequent tree is iteratively fitted to the residuals of the previous model as long as it is necessary (Elith et al., 2008). The models were fitted with R (v. 3.1.3; R Development Core Team, 2015) package 'dismo' (v. 1.012; Hijmans et al., 2016). In addition to elevation, radiation, wetness and TPI, site (fell massif) was used as a categorical variable to test whether the sampling location had an effect to the results. As strong correlations among the explanatory variables can distort statistical models (Graham, 2003), a criteria of $|\mathrm{r}|>0.7$ was set for Pearson correlation coefficient between each explanatory variables (Appendix 2, Dormann et al., 2013). Relative influence $(R I)$ of each predictor variable was estimated based on 1) how many times each variable was selected, and 2) improvement in model fit when the variable was included (Elith et al., 2008; Friedman, 2001). Interactions between the explanatory variables were finally tested with gmb.interact function (Elith et al., 2008; Hijmans et al., 2016). All the models were fit for alpine plots (no trees present), forest plots (treespresent) and full data separately. Finally, to inspect the modelling results spatially, a full data model and the LSP rasters were used to predict continuous AGB estimates for the study area.

\section{Results}




\subsection{Relationship of aboveground biomass and NDVI}

The relationship between AGB and NDVI was exponential with saturation of NDVI occurring in the forest zone (Fig 2b). The model for the full data explained $61.5 \%$ of the variance. In general, the relationship between AGB and NDVI is heteroscedastic as variance in NDVI strongly increases with higher AGB (Fig. 2a).
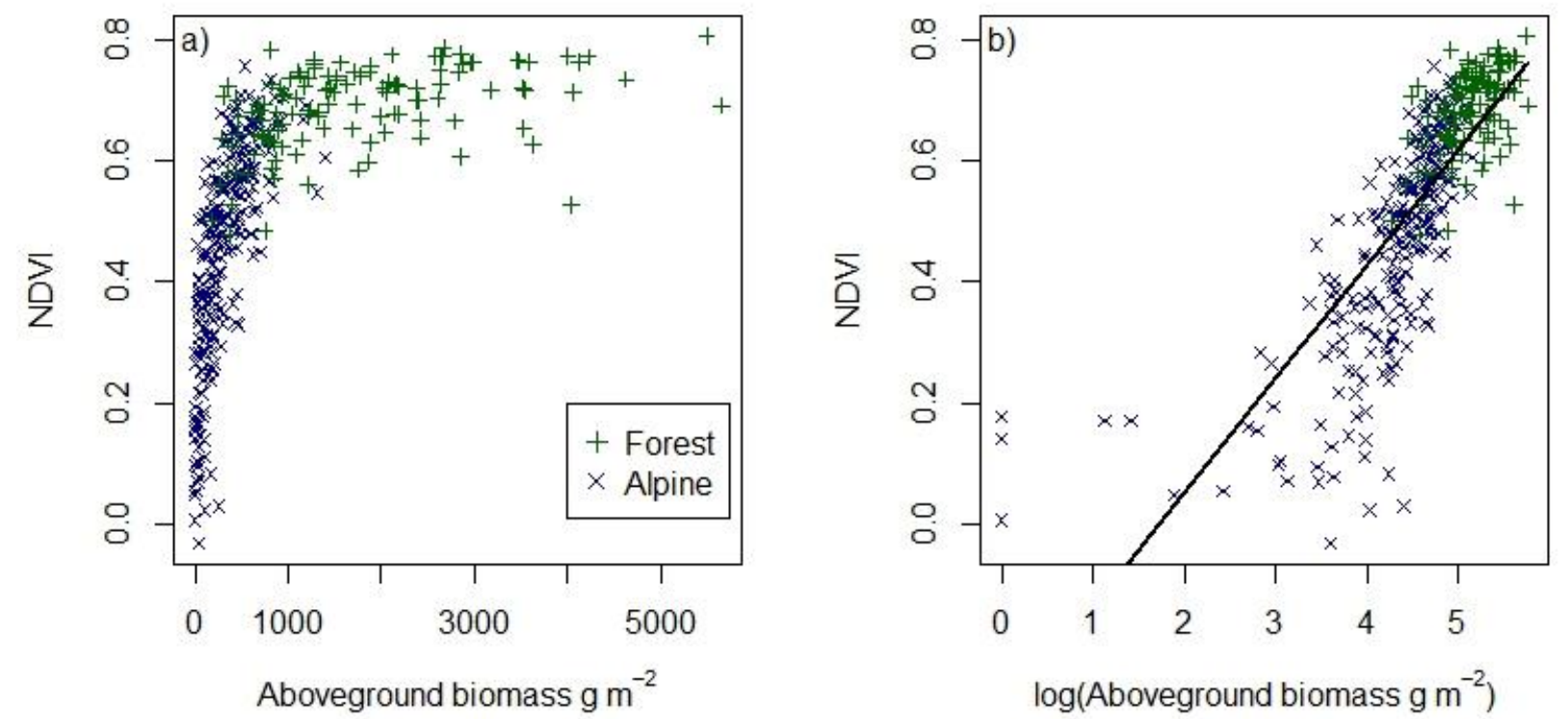

Figure 2. The relationship of (a) AGB and NDVI and (b) log-transformed AGB and NDVI with fitted linear model ( $\mathrm{R}^{2}$ $=0.615$ ).

\subsection{Responses of aboveground biomass and NDVI to land surface parameters}

In the BRT models, the explained deviance (cross-validated $\mathrm{D}^{2}$ ) for AGB was $51 \%, 41 \%$ and $12 \%$ for full, alpine and forest data, respectively. Elevation and radiation were the most influential LSPs (Fig. 3b, 3c). The location of forestline (around 550-600 m. a.s.1.) and treeline (around 600-740 m. a.s.1.) can be clearly seen from the smoothed response curves (Fig. 3a). The effect of radiation becomes visible at around $4200 \mathrm{MJ} \mathrm{m}^{-2}$ $\mathrm{a}^{-1}$, after which the response is increasingly positive. Below the treeline, wetness has a positive response in the AGB model, but no apparent response in the alpine zone. TPI300 had a large influence to AGB model indicating that large AGB are found from protected landscapes, however TPI50 showed contrasting response with the forest data. At the alpine zone, the role of TPI was overall very small and both TPI response curves appeared flat. Sampling site had high influence in the forest model (Fig 3b). 

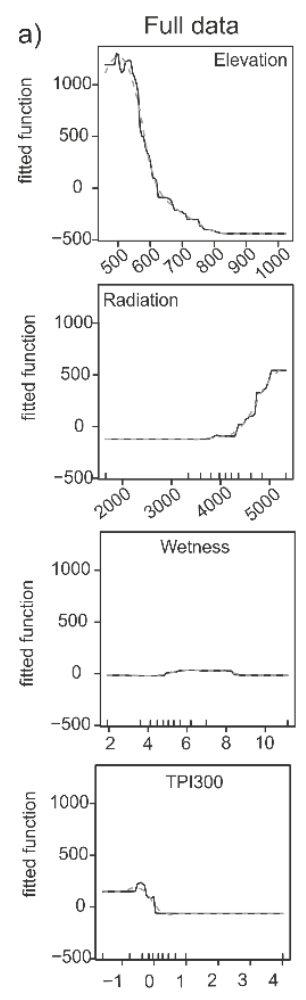

Forest
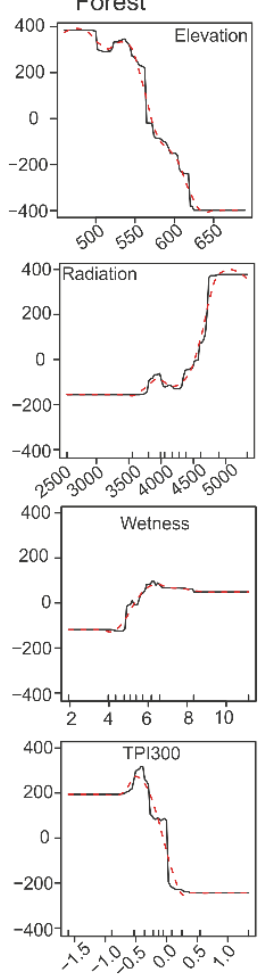
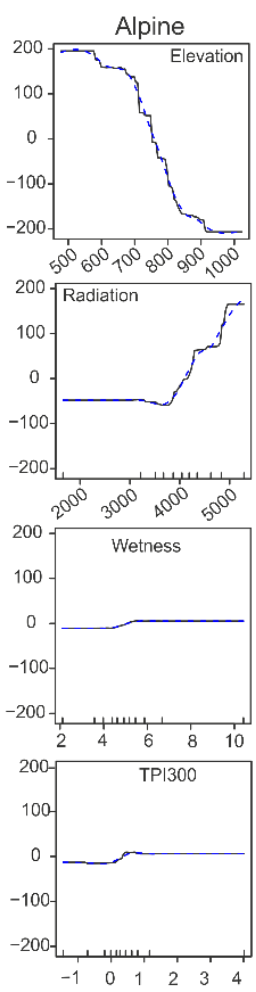
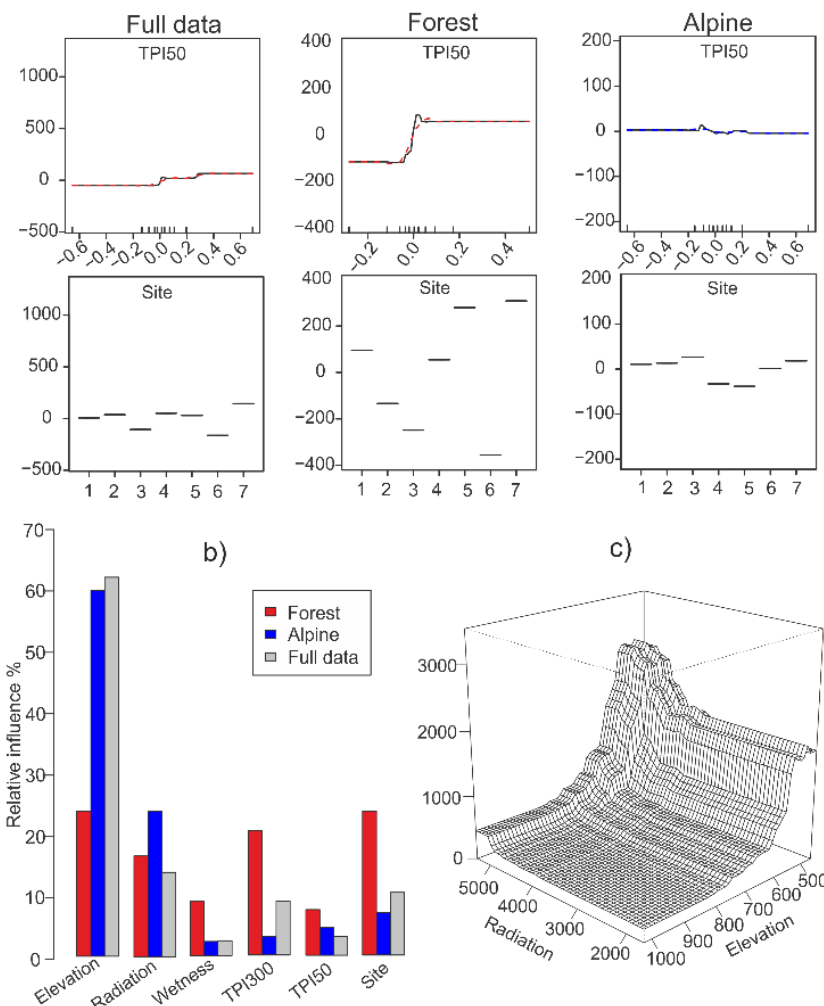

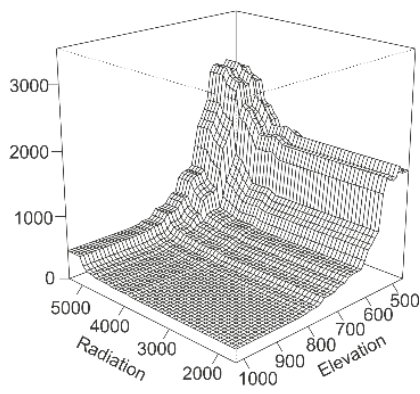

Figure 3. Boosted regression tree (BRT) modelling results for aboveground biomass. (a) Smoothed response curves of the land surface parameters (LSPs). Y-axis shows the fitted function value $\left(\mathrm{g} \mathrm{m}^{-2}\right)$. Elevation $=\mathrm{m}$. a.s.l.; Radiation $=$ Potential Incoming Solar Radiation, $\mathrm{MJ} \mathrm{m}^{-2} \mathrm{a}^{-1}$; Wetness = SAGA Wetness Index; TPI300 = Topographic Position Index, 300 m radius; TPI50 = Topographic Position Index, $50 \mathrm{~m}$ radius. Partial dependency functions visualize the dependency between the fitted response and each predictor. The shape of the partial dependency function reflects the effect shape and the range is proportional to the relative contribution of the predictor (Friedman, 2001). (b) The relative influence of each LSP on the model. (c) The most significant interaction between the LSPs, where Y-axis is the fitted function value for the response variable.

The explained deviances were consistently higher for NDVI models. $\mathrm{D}^{2}$ was $66 \%$ for the full data, $58 \%$ for the alpine and $21 \%$ for the forest data. Similarly to AGB, elevation and radiation were the most influential LSPs (Fig. 4b, 4c). However, the response curves differed between the AGB and NDVI models. In the full model for NDVI, the response curve of elevation is smooth compared to AGB model and the location of the treeline is hardly visible from the responses (Fig. 4a). Moreover, the relationship between radiation and NDVI is also different as the response starts to be positive already ca. $500 \mathrm{MJ} \mathrm{m}^{-2} \mathrm{a}^{-1}$ lower values than in the AGB models. The topographic wetness and TPI 300 have only minor influence on the NDVI models. However, TPI50 had strong influence on the forest model, where protected landforms had relatively high NDVI. Interestingly, in the alpine zone, the effect was reversed. TPI300 had only small relative influence on all of the NDVI models. Effect of sampling site below the treeline was small compared to AGB model. 

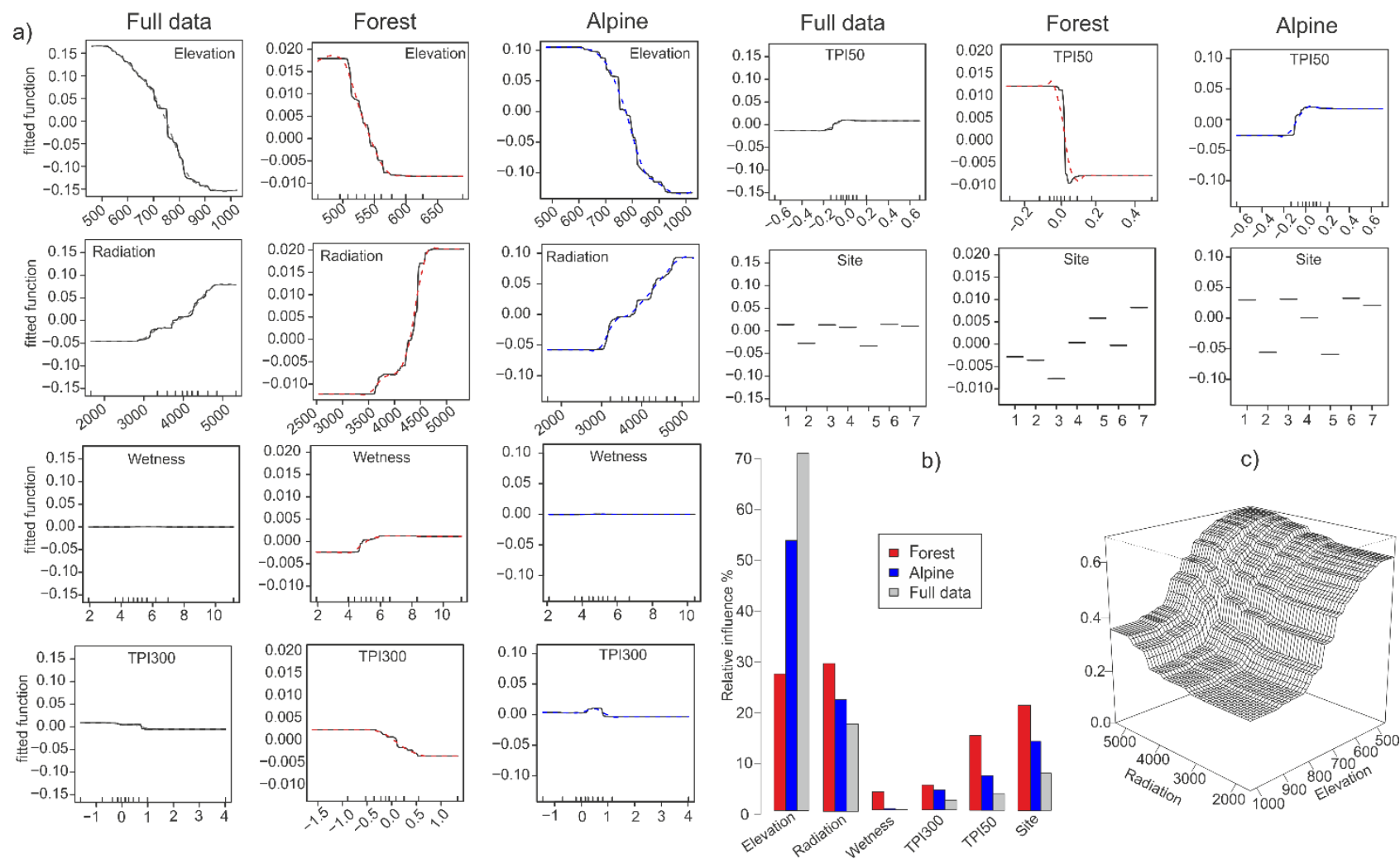

c)

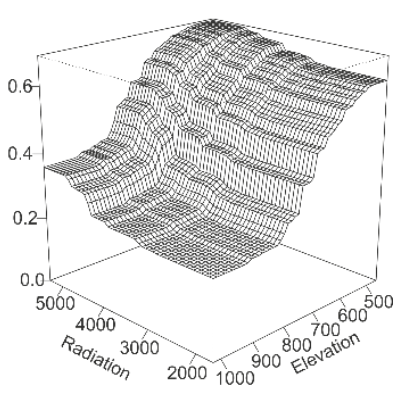

Figure 4. NDVI BRT model results: (a) Smoothed response curves of the LSPs to NDVI. Y-axis is for fitted function value. (b) The relative influence of each LSP to the boosted regression tree model. (c) Most significant interaction between the LSPs, where Y-axis is the fitted function value for the response variable. See further details from Fig. 3 caption.

The radiation had a clear positive effect on both AGB and NDVI (Fig. 3a and Fig. 4a) Furthermore, radiation and elevation had a significant interaction, showing that the highest fitted values were found from lowelevation and high-radiation sites (Figs. 3c and 4c), which are typically located in the south-southwest facing valley slopes (Fig. 5). The spatial prediction of the full data AGB model and a close up look to the explanatory variables (Fig. 5) reveals the same effects as seen from response curves (Fig. 3a). High-radiation and protected (negative TPI300-values) sites at low-elevations have the highest AGB-values and one can clearly see that AGB (nor NDVI) does not simply change as a function of elevation alone (Fig. 5). All of the BRT-models were run twice, first with single extracted pixel data and secondly with focal mean or median raster data to test whether GPS accuracy has an effect to the models. Using focal data did no improve the models. Therefore, only results based on single pixel values were represented. 

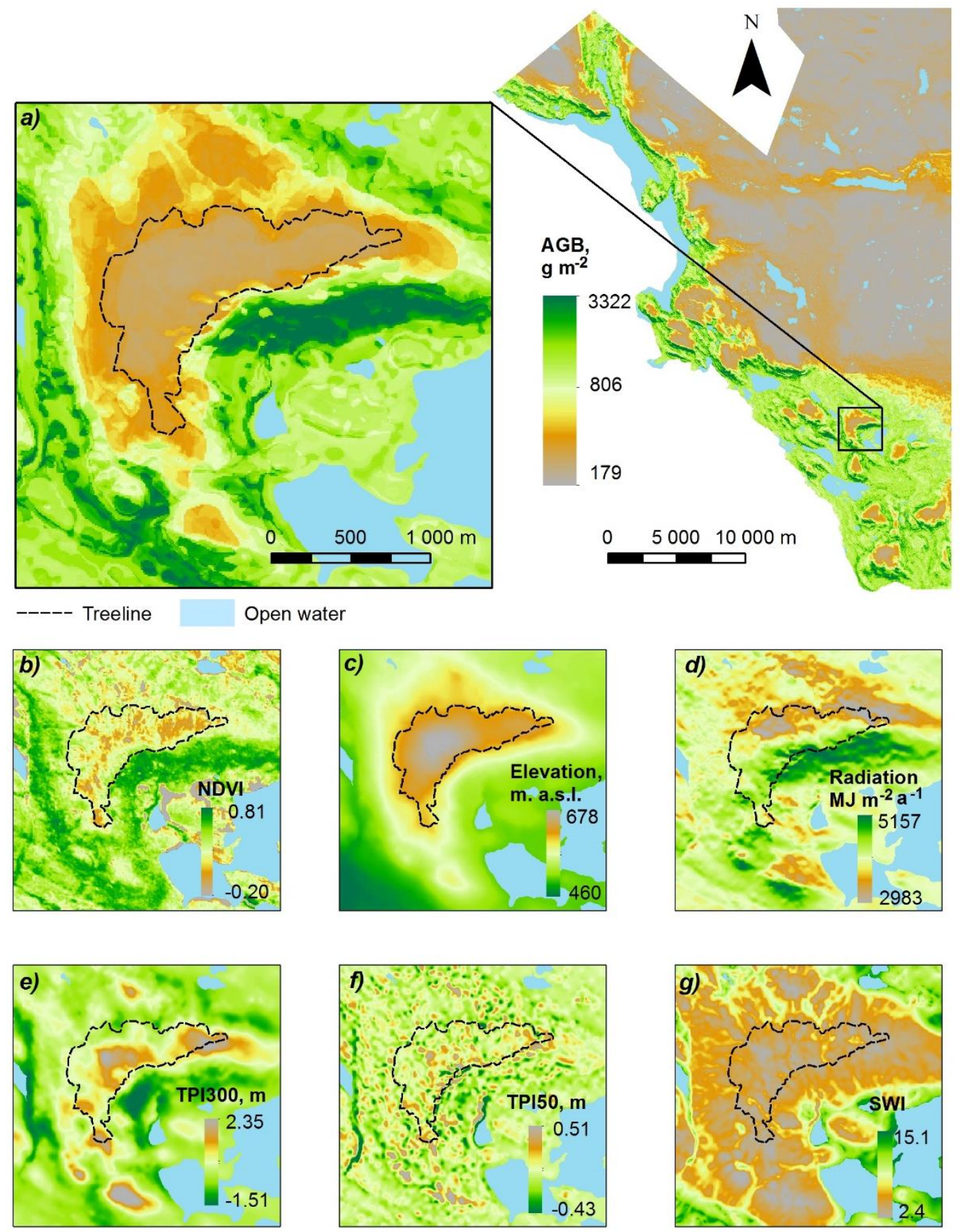

Figure 5. (a) Predicted AGB for the study area and a close-up look of Suppivaara fell; (b) SPOT5 HRG NDVI; (c) Elevation $=$ m. a.s.l.; (d) Radiation $=$ Potential Incoming Solar Radiation, $\mathrm{MJ} \mathrm{m}^{-2} \mathrm{a}^{-1}$; (e) TPI300 $=$ Topographic Position Index, 300 m radius; (f) TPI50 = Topographic Position Index, $50 \mathrm{~m}$ radius; (g) SWI = SAGA Wetness Index. Treeline was interpreted from aerial imagery (2012) and lakes extracted from the topographic database of Finland, both downloaded from open file service of the National Land Survey of Finland (NLS, 2016b). 


\section{Discussion}

Substantial spatial variation was observed in aboveground biomass (AGB) and NDVI, as has been previously reported for the high-latitude areas (Johansen and Tømmervik, 2014). The relationship between AGB and NDVI indicates that NDVI has poor sensitivity to variation in AGB at high NDVI values corresponding to mountain birch forests (Fig. 2). This saturation effect has been observed in many previous studies and ecosystems (Heiskanen, 2006; Jones and Vaughan, 2010; Wang et al., 2005). This limits the use of NDVI as a predictor of AGB in dense forests, which was further confirmed by the different responses against the studied LSPs. Other spectral vegetation indices have been proposed to be used instead of NDVI to take into account the effect of background reflectance (Chen et al., 2002; Jones and Vaughan, 2010), for example simple ratio based indices might suit better for forest environments.

The local variation of aboveground biomass was strongly controlled by topographical heterogeneity (Fig. 5). For the full models the cross validated explained deviance for AGB was $51 \%$ and $66 \%$ for NDVI. Multiple LSPs contributed to explaining variation in AGB and NDVI, reflecting the multivariate nature of the environmental constraints on vegetation productivity and biomass accumulation (Fisk et al., 1998; Suvanto et al., 2014). Our results suggest that the importance of topography to AGB is largely due to its effect to thermal conditions of the sites (Tranquillini, 1979; Walker et al., 2003), but also related to soil properties and snow persistence (Broll et al., 2007; Fisk et al., 1998; Walker et al., 1993). However, the effects of topographic position were only seen at the landscape scale below the treeline. Physical disturbances caused by geomorphological processes also affect species composition and productivity (le Roux and Luoto, 2014; Virtanen et al., 2010), but based on these analyses it is hard to make further conclusions from their effect on AGB or NDVI.

Elevation was the most important explanatory variable as was expected. It controls four primary environmental gradients: 1) barometric pressure, 2) adiabatic reduction of atmospheric temperature, 3) clear sky radiation and 4) increasing fraction of UV radiation in solar radiation (Körner, 2012). In particular, the strong effect on AGB can be explained by ca. $-0.65{ }^{\circ} \mathrm{C} / 100 \mathrm{~m}$ adiabatic lapse rate, which effects growing season length, growing degree days, the potential for photosynthesis and nutrient availability (Tømmervik et al., 2005). In all of the AGB models, the response curves steeply declined when moving upward along the elevation gradient, especially in the treeline ecotone (c. 550-740 m. a.s.l.). In the forest models, elevation had less influence compared to the full data and alpine models. It is possible that the existence of trees diminishes the effect of topography inside forest. Under the forest canopy, the environmental conditions are much more stable than in the open tundra, for example, snow redistribution and its effects are more pronounced outside the forest zone (Holtmeier, 2003). However, it must be noted that the forest data also included treeline data where the canopy cover is low $(<10 \%)$. In the NDVI models, elevation had smooth response curve in comparison to the AGB models. This is possibly due to background reflectance of the field and shrub layers, which play an important 
role in canopy reflectance of sparse mountain birch forests (Heiskanen, 2006). This could also explain why NDVI remains high even if AGB declines steeply in the treeline. The relative influence of elevation in various models highlights that elevation is the main driver for temperature related growing conditions.

Potential incoming solar radiation makes it possible to model the thermal growing conditions more realistically compared to elevation only (Böhner and Antonić, 2009). The interaction of radiation and elevation was also found important regarding both AGB and NDVI. Radiation had a positive response after around 4100-4500 $\mathrm{MJ} \mathrm{m}^{-2} \mathrm{a}^{-1}$ in all the AGB models (Fig. 3, Fig. 5). In the northern hemisphere the highest radiation values are found from steep south facing slopes, while north facing slopes receive far less potential incoming solar radiation (Fig. 5). Below the treeline, the response curve of the NDVI model was very similar to that of the AGB model. In the alpine zone, NDVI had a positive effect from $c a .3700 \mathrm{MJ} \mathrm{m}^{-2} \mathrm{a}^{-1}$, possibly due the high NDVI close to the treeline caused by abundant shrubs. The overall effect of radiation on AGB is a sum of at least three different mechanisms; 1) thermal radiation, which affects the start and end of the growing season, air and soil temperatures, which again is linked to nutrient release and primary production, 2) photosynthetically active radiation, which is directly linked to photosynthetic capacity and biomass accumulation, and 3) $U V-B$ radiation, which can potentially cause damage to plant tissue (Turunen and Latola, 2005). The overall effect of radiation clearly is positive in this case. Arctic and alpine areas are frequently covered by clouds, thus causing actual incoming solar radiation (AISR) to be less than PISR. Although it would be a more precise measure to use, AISR was not used, as the focus of this study is solely on DEM based variables. Furthermore, no high-resolution cloud product exists at the moment to our knowledge, while the PISR still reveals the landscape to local scale differences on radiation distribution (Fig. 5).

Topographic position controls nutrient availability and soil moisture conditions and has been linked to productivity and aboveground biomass (Billings and Mooney, 1968; Broll et al., 2007; Fisk et al., 1998). The used topographic position algorithm (Guisan et al., 1999; Weiss, 2001) is controlled by the radius parameter. Two radii were tested to study local and landscape scale effects of the topographic position, neither of which showed consistent response to AGB. With the forest data the two radii had contrasting responses. The results indicate that when the landscape scale location is protected, higher AGB occur at sites which are slightly higher than their immediate surroundings. However, the same effect was not apparent in the NDVI model for forests. In the NDVI model for alpine areas, TPI50 showed positive response. One possible explanation is that these sites melt earlier than protected sites and thus have higher NDVI. Based on the previous work (Billings and Mooney, 1968; Broll et al., 2007; Fisk et al., 1998; Holtmeier, 2003), it wasexpected that slightly negative (i.e., protected) topographic position would have been suitable for higher NDVI, similar to AGB model for forests. 
The role of topographic wetness was minor in all the models with the exception of AGB model for the forest, where AGB was the highest at intermediate wetness values. The highest wetness is found at valley bottoms and around lakes or ponds, where flow accumulation area is high, and where the slope is low (see Eq. 2, Fig. 5). As mountain birch prefers slope environments (Poso and Kujala, 1973), it is possible that the highest fitted values are not found where the topographic wetness is the highest, as higher slope decreases SWI. Also dry environments have a clear negative effect on biomass accumulation.

Possibilities for future development would be testing 1) seasonal remote sensing data instead of peak biomass data (Heiskanen and Kivinen, 2008; Zhu and Liu, 2015), 2) specific indices for high-biomass strata, such as shrubs (Kushida et al., 2015), and 3) multiangular data (Heiskanen and Kivinen, 2008). Combining various medium resolution image sources (e.g. Landsat and Sentinel) would provide sufficient temporal resolution for seasonal analysis. The limitations of the NDVI at the forest zone indicate that novel methods should be applied when studying the areas which have multiple layers of vegetation (i.e. trees and understory). One example of novel techniques is Light detection and Ranging (LiDAR), which is extremely useful technique to map biomass of trees and shrubs (Greaves et al., 2015; Nyström et al., 2012) and topography. However, currently there are no global, nor circumpolar LiDAR products at medium or high resolution, whereas global high resolution DEM $(<30 \mathrm{~m})$ and optical remote sensing data are available. In Arctic tundra where there is less vegetation the aforementioned issues should not be a problem.

\section{Conclusions}

Topoclimatic variables, namely elevation and radiation and their interaction, had the most important role behind aboveground biomass (AGB) and NDVI distribution. The highest AGB were found from low-elevation, south-southwest facing slopes, covered by mountain birch forests. Topographic position and wetness had mixed, generally weak responses, although the negative topographic position at landscape scale seemed to be more favorable below the treeline. Results imply that although NDVI is the highest below the treeline it is also affected by field layer and shrubs, thus NDVI appears to be less sensitive to topography, elevation in particular, compared to AGB. In this study a solid evidence was presented s that topoclimatic variables, specifically elevation together with potential incoming solar radiation, can be used for modelling AGB patterns in arcticalpine environments. DEM is a valuable resource when locating areas which are suitable for high biomass, as a result of land form control of local growing conditions. Furthermore, DEM derivatives offers possibilities to downscale coarse resolution estimates of biomass, such as derived based on AVHRR and MODIS data. 


\section{Acknowledgements}

We wish to thank Lantmäteriet and SACCESS service for providing the satellite data and field workers, especially Oona Helander and Tuija Pyykkönen, who helped to obtain the field reference data. This work was supported by Ympäristön ystävät rahasto and Nordenskiöld samfundet. Henri Riihimäki receives funding from GeoDoc doctoral program, University of Helsinki.

\section{References}

Barrachina, M., Cristobal, J., Tulla, A.F., 2015. Estimating above-ground biomass on mountain meadows and pastures through remote sensing. International Journal of Applied Earth Observation and Geoinformation 38, 184-192, http://dx.doi.org/10.1016/j.jag.2014.12.002.

Berdanier, A.B., Klein, J.A., 2011. Growing Season Length and Soil Moisture Interactively Constrain High Elevation Aboveground Net Primary Production. Ecosystems 14, 963-974, http://dx.doi.org/10.1007/s10021-011-9459-1.

Billings, W.D., Mooney, H.A., 1968. Ecology of Arctic and Alpine Plants. Biological Reviews of the Cambridge Philosophical Society 43, 481-529, http://dx.doi.org/10.1111/j.1469-185X.1968.tb00968.x.

Blok, D., Schaepman-Strub, G., Bartholomeus, H., Heijmans, M.M.P.D., Maximov, T.C., Berendse, F., 2011. The response of Arctic vegetation to the summer climate: relation between shrub cover, NDVI, surface albedo and temperature. Environmental Research Letters 6, 035502, http://dx.doi.org/10.1088/1748-9326/6/3/035502

Broll, G., Holtmeier, F.K., Anschlag, K., Brauckmann, H.-J., Wald, S., Drees, B., 2007. Landscape mosaic in the treeline ecotone on Mt Rodjanoaivi, Subarctic Finland. Fennia 185, 89-105

Bruun, H.H., Moen, J., Virtanen, R., Grytnes, J.A., Oksanen, L., Angerbjorn, A., 2006. Effects of altitude and topography on species richness of vascular plants, bryophytes and lichens in alpine communities. Journal of Vegetation Science 17, 37-46, http://dx.doi.org/10.1111/j.1654-1103.2006.tb02421.x.

Böhner, J., Antonić, O., 2009. Land Surface Parameters Specific to Topo-Climatology, in: Hartemink, A.E., McBratney, A.B. (Eds.), Geomorphometry - Concepts, Software, Applications. Elsevier, Amsterdam, pp. 195-226.

Böhner, J., Selige, T., 2006. Spatial prediction of soil attributes using terrain analysis and climate regionalisation, in: Böhner, J., McCloy, K.R., Strobl, J. (Eds.), SAGA - Analyses and Modelling Applications. Verlag Erich Goltze GmbH, pp. 13-27.

Chapin, F.S., Fetcher, N., Kielland, K., Everett, K.R., Linkins, A.E., 1988. Productivity and Nutrient Cycling of Alaskan Tundra: Enhancement by Flowing Soil Water. Ecology 69, 693-702, http://dx.doi.org/10.2307/1941017

Chen, J.M., Pavlic, G., Brown, L., Cihlar, J., Leblanc, S.G., White, H.P., Hall, R.J., Peddle, D.R., King, D.J., Trofymow, J.A., Swift, E., Van der Sanden, J., Pellikka, P.K.E., 2002. Derivation and validation of Canada-wide coarse-resolution leaf area index maps using high-resolution satellite imagery and ground measurements. Remote Sensing of Environment 80, 165-184, http://dx.doi.org/10.1016/S00344257(01)00300-5.

Dobrowski, S.Z., 2011. A climatic basis for microrefugia: the influence of terrain on climate. Global Change Biology 17, 1022-1035, http://dx.doi.org/10.1111/j.1365-2486.2010.02263.x.

Dobrowski, S.Z., Abatzoglou, J.T., Greenberg, J.A., Schladow, S.G., 2009. How much influence does landscape-scale physiography have on air temperature in a mountain environment? Agricultural and Forest Meteorology 149, 1751-1758, http://dx.doi.org/10.1016/j.agrformet.2009.06.006.

Dormann, C.F., Elith, J., Bacher, S., Buchmann, C., Gudrun, C., Carre, G., Marquéz, J.R.G., Gruber, B., Lafourcade, B., Leitão, P.J., Münkemüller, T., McClean, C., Osborne, P.E., Reineking, B., Schröder, B., Skidmore, A.K., Zurell, D., Lautenbach, S., 2013. Collinearity: a review of methods to deal with it and a simulation study evaluating their performance. Ecography 36, 27-46, http://dx.doi.org/10.1111/j.1600-0587.2012.07348.x.

Elith, J., Leathwick, J.R., Hastie, T., 2008. A working guide to boosted regression trees. Journal of Animal Ecology 77, 802-813, http://dx.doi.org/10.1111/j.1365-2656.2008.01390.x. 
Epstein, H.E., Raynolds, M.K., Walker, D.A., Bhatt, U.S., Tucker, C.J., Pinzon, J.E., 2012. Dynamics of aboveground phytomass of the circumpolar Arctic tundra during the past three decades.

Environmental Research Letters 7, 12, http://dx.doi.org/10.1088/1748-9326/7/1/015506.

Eurola, S., Huttunen, S., Welling, P., 2003. Enontekiön suurtuntureiden $\left(68^{\circ} 45^{\prime}-69^{\circ} 17\right.$ N $\left.; 20^{\circ} 45^{\prime}-22^{\circ} \mathrm{E}\right)$ paljakkakasvillisuus [Vegetation on the fjelds of NW Enontekiö, Finnish Lapland $\left(68^{\circ} 45^{\prime}-69^{\circ} 17^{\prime} \mathrm{N}\right.$; $\left.\left.20^{\circ} 45^{\prime}-22^{\circ} \mathrm{E}\right)\right]$. Kilpisjärvi Notes $17,28 \mathrm{p}$.

Fisk, M.C., Schmidt, S.K., Seastedt, T.R., 1998. Topographic patterns of above- and belowground production and nitrogen cycling in Alpine tundra. Ecology 79, 2253-2266, http://dx.doi.org/10.1890/0012-9658(1998)079[2253:tpoaab]2.0.co;2.

Franklin, J., 1995. Predictive vegetation mapping: Geographic modelling of biospatial patterns in relation to environmental gradients. Progress in Physical Geography 19, 474-499, http://dx.doi.org/10.1177/030913339501900403.

Friedman, J.H., 2001. Greedy function approximation: A gradient boosting machine. Annals of Statistics 29, 1189-1232, http://dx.doi.org/10.1214/aos/1013203451.

Graham, M.H., 2003. Confronting multicollinearity in ecological multiple regression. Ecology 84, 28092815, http://dx.doi.org/10.1890/02-3114.

Greaves, H.E., Vierling, L.A., Eitel, J.U.H., Boelman, N.T., Magney, T.S., Prager, C.M., Griffin, K.L., 2015. Estimating aboveground biomass and leaf area of low-stature Arctic shrubs with terrestrial LiDAR. Remote Sensing of Environment 164, 26-35, http://dx.doi.org/10.1016/j.rse.2015.02.023.

Guisan, A., Weiss, S.B., Weiss, A.D., 1999. GLM versus CCA spatial modeling of plant species distribution. Plant Ecology 143, 107-122, http://dx.doi.org/10.1023/A:1009841519580.

Heiskanen, J., 2006. Estimating aboveground tree biomass and leaf area index in a mountain birch forest using ASTER satellite data. International Journal of Remote Sensing 27, 1135-1158, http://dx.doi.org/10.1080/01431160500353858.

Heiskanen, J., Kivinen, S., 2008. Assessment of multispectral, -temporal and -angular MODIS data for tree cover mapping in the tundra-taiga transition zone. Remote Sensing of Environment 112, 2367-2380, http://dx.doi.org/10.1016/j.rse.2007.11.002.

Hijmans, R.J., Phillips, S.J., Leathwick, J., Elith, J., 2016. Package 'dismo'. https://cran.rproject.org/web/packages/dismo/dismo.pdf. Accessed 28.06.2016

Hjort, J., Luoto, M., 2009. Interaction of geomorphic and ecologic features across altitudinal zones in a subarctic landscape. Geomorphology 112, 324-333, http://dx.doi.org/10.1016/j.geomorph.2009.06.019.

Holtmeier, F.K., 2003. Mountain Timberlines: Ecology, Patchiness, and Dynamics. Kluwer Academic Publishers, Dordrecht, 369 p.

Jiang, Z.Y., Huete, A.R., Chen, J., Chen, Y.H., Li, J., Yan, G.J., Zhang, X.Y., 2006. Analysis of NDVI and scaled difference vegetation index retrievals of vegetation fraction. Remote Sensing of Environment 101, 366-378, http://dx.doi.org/10.1016/j.rse.2006.01.003.

Johansen, B., Tommervik, H., 2014. The relationship between phytomass, NDVI and vegetation communities Svalbard. International Journal of Applied Earth Observation and Geoinformation 27, 20-30, http://dx.doi.org/10.1016/j.jag.2013.07.001.

Jones, H.G., Vaughan, R.A., 2010. Remote sensing of vegetation: principles, techniques and applications. Oxford University Press, Oxford ; New York, 353 p.

Järvinen, A., Partanen, R., 2008. Stand dynamics of mountain birch, Betula pubescens ssp. czerepanovii (Orlova) Hämet-Ahti, in NW Finnish Lapland. Kilpisjärvi Notes 21, 16 p.

Kushida, K., Hobara, S., Tsuyuzaki, S., Kim, Y., Watanabe, M., Setiawan, Y., Harada, K., Shaver, G.R., Fukuda, M., 2015. Spectral indices for remote sensing of phytomass, deciduous shrubs, and productivity in Alaskan Arctic tundra. International Journal of Remote Sensing 36, 4344-4362, http://dx.doi.org/10.1080/01431161.2015.1080878.

Käyhkö, J., Pellikka, P., 1994. Remote sensing of the impact of reindeer grazing on vegetation in northern Fennoscandia using Spot XS data. Polar Research 13, 115-124, http://dx.doi.org/10.1111/j.17518369.1994.tb00442.x.

Körner, C., 2012. Alpine Treelines - Functional Ecology of the Global High Elevation Tree Limits. Springer, New York, $220 \mathrm{p}$.

Larcher, W., Kainmuller, C., Wagner, J., 2010. Survival types of high mountain plants under extreme temperatures. Flora 205, 3-18, http://dx.doi.org/10.1016/j.flora.2008.12.005. 
le Roux, P.C., Luoto, M., 2014. Earth surface processes drive the richness, composition and occurrence of plant species in an arctic-alpine environment. Journal of Vegetation Science 25, 45-54, http://dx.doi.org/10.1111/jvs.12059.

McCune, B., Grace, J.B., Urban, D.L., 2002. Analysis of ecological communities. MjM Software Design, Gleneden Beach, OR, 300 p.

Mikkola, K., Sepponen, P., 1986. Kasvupaikkatekijöiden ja kasvillisuuden suhteet luoteis-enontekiön tunturikoivikoissa [Relationships between site factors and vegetation in mountain birch stands in northwestern Enontekiö]. Metsäntutkimuslaitos, Helsinki, 30 p.

Moore, I.D., Gessler, P.E., Nielsen, G.A., Peterson, G.A., 1993. Soil Attribute Prediction Using Terrain Analysis. Soil Science Society of America Journal 57, 443-452, http://dx.doi.org/10.2136/sssaj1993.572NPb.

Moore, I.D., Grayson, R.B., Ladson, A.R., 1991. Digital terrain modeling - a review of hydrological, geomorphological, and biological applications. Hydrological Processes 5, 3-30, http://dx.doi.org/10.1002/hyp.3360050103.

Myneni, R.B., Keeling, C.D., Tucker, C.J., Asrar, G., Nemani, R.R., 1997. Increased plant growth in the northern high latitudes from 1981 to 1991. Nature 386, 698-702, http://dx.doi.org/10.1038/386698a0.

NLS (National Land Survey of Finland), 2016a. Elevation model $10 \mathrm{~m}$ - Product description. http://www.maanmittauslaitos.fi/en/digituotteet/elevation-model-10-m. (accessed 18.2.2015).

NLS (National Land Survey of Finland), 2016b. File service of open data. https://tiedostopalvelu.maanmittauslaitos.fi/tp/kartta?lang=en. (accessed 18.2.2015, 20.01.2016).

Nyström, M., Holmgren, J., Olsson, H., 2012. Prediction of tree biomass in the forest-tundra ecotone using airborne laser scanning. Remote Sensing of Environment 123, 271-279, http://dx.doi.org/10.1016/j.rse.2012.03.008.

Poso, S., Kujala, M., 1973. The Effect of Topography on the Volume of Forest Growing Stock. Metsäntutkimuslaitos, Helsinki, 26 p.

R Development Core Team, 2015. R: The R Project for Statistical Computing. https://www.r-project.org/.

Raynolds, M.K., Walker, D.A., Epstein, H.E., Pinzon, J.E., Tucker, C.J., 2012. A new estimate of tundrabiome phytomass from trans-Arctic field data and AVHRR NDVI. Remote Sensing Letters 3, 403 411, 10.1080/01431161.2011.609188.

Scherrer, D., Körner, C., 2011. Topographically controlled thermal-habitat differentiation buffers alpine plant diversity against climate warming. Journal of Biogeography 38, 406-416, http://dx.doi.org/10.1111/j.1365-2699.2010.02407.x.

Song, C., Woodcock, C.E., Seto, K.C., Lenney, M.P., Macomber, S.A., 2001. Classification and change detection using Landsat TM data: When and how to correct atmospheric effects? Remote Sensing of Environment 75, 230-244, http://dx.doi.org/10.1016/S0034-4257(00)00169-3.

Stewart, K.J., Grogan, P., Coxson, D.S., Siciliano, S.D., 2014. Topography as a key factor driving atmospheric nitrogen exchanges in arctic terrestrial ecosystems. Soil Biology and Biochemistry 70, 96-112, http://dx.doi.org/doi:10.1016/j.soilbio.2013.12.005.

Sturm, M., Racine, C., Tape, K., 2001. Climate change: Increasing shrub abundance in the Arctic. Nature 411, 546-547, http://dx.doi.org/10.1038/35079180.

Suvanto, S., Le Roux, P.C., Luoto, M., 2014. Arctic-alpine vegetation biomass is driven by fine-scale abiotic heterogeneity. Geografiska Annaler: Series A, Physical Geography 96, 549-560, http://dx.doi.org/10.1111/geoa.12050.

Tonolli, S., Dalponte, M., Neteler, M., Rodeghiero, M., Vescovo, L., Gianelle, D. 2011. Fusion of airborne LiDAR and satellite multispectral data for the estimation of timber volume in the Southern Alps. Remote Sensing of Environment 10, 2486-2498.

Tranquillini, W., 1979. Physiological ecology of the Alpine timberline: tree existence at high altitudes with special reference to the European Alps. Springer-Verlag, Berlin ; New York, 137 p.

Tucker, C.J., 1979. Red and Photographic Infrared Linear Combinations for Monitoring Vegetation. Remote Sensing of Environment 8, 127-150, http://dx.doi.org/10.1016/0034-4257(79)90013-0.

Turunen, M., Latola, K., 2005. UV-B radiation and acclimation in timberline plants. Environmental Pollution 137, 390-403, http://dx.doi.org/10.1016/j.envpol.2005.01.030.

Tømmervik, H., Wielgolaski, F.E., Neuvonen, S., Solberg, B., Høgda, K.A., 2005. Biomass and Production on a Landscape Level in the Mountain Birch Forests, in: Wielgolaski, F.E. (Ed.), Plant Ecology, Herbivory, and Human Impact in Nordic Mountain Birch Forests. Springer, pp. 55-70. 
Walker, D.A., Epstein, H.E., Jia, G.J., Balser, A., Copass, C., Edwards, E.J., Gould, W.A., Hollingsworth, J., Knudson, J., Maier, H.A., Moody, A., Raynolds, M.K., 2003. Phytomass, LAI, and NDVI in northern Alaska: Relationships to summer warmth, soil $\mathrm{pH}$, plant functional types, and extrapolation to the circumpolar Arctic. Journal of Geophysical Research-Atmospheres 108, http://dx.doi.org/10.1029/2001jd000986.

Walker, D.A., Halfpenny, J.C., Walker, M.D., Wessman, C.A., 1993. Long-Term Studies of SnowVegetation Interactions. BioScience 43, 287-301, http://dx.doi.org/10.2307/1312061.

Wang, L., Liu, H., 2006. An efficient method for identifying and filling surface depressions in digital elevation models for hydrologic analysis and modelling. International Journal of Geographical Information Science 20, 193-213, http://dx.doi.org/10.1080/13658810500433453.

Wang, Q., Adiku, S., Tenhunen, J., Granier, A., 2005. On the relationship of NDVI with leaf area index in a deciduous forest site. Remote Sensing of Environment 94, 244-255, http://dx.doi.org/10.1016/j.rse.2004.10.006.

Weiss, A.D., 2001. Topographic Position and Landform Analysis, ESRI International User Conference San Diego, CA

Wilson, J.P., Gallant, J.C., 2000. Terrain analysis : principles and applications. Wiley, New York, 479 p.

Virtanen, R., Luoto, M., Rama, T., Mikkola, K., Hjort, J., Grytnes, J.A., Birks, H.J.B., 2010. Recent vegetation changes at the high-latitude tree line ecotone are controlled by geomorphological disturbance, productivity and diversity. Global Ecology and Biogeography 19, 810-821, http://dx.doi.org/10.1111/j.1466-8238.2010.00570.x.

Virtanen, R., Oksanen, L., Oksanen, T., Cohen, J., Forbes, B.C., Johansen, B., Käyhkö, J., Olofsson, J., Pulliainen, J., Tømmervik, H., 2016. Where do the treeless tundra areas of northern highlands fit in the global biome system: toward an ecologically natural subdivision of the tundra biome. Ecology and Evolution 6, 143-158, http://dx.doi.org/10.1002/ece3.1837.

Xie, Y.C., Sha, Z.Y. \& Yu, M. (2008) Remote sensing imagery in vegetation mapping: a review. Journal of Plant Ecology, 1, 9-23.

Zhu, X.L., Liu, D.S., 2015. Improving forest aboveground biomass estimation using seasonal Landsat NDVI time-series. Isprs Journal of Photogrammetry and Remote Sensing 102, 222-231, http://dx.doi.org/10.1016/j.isprsjprs.2014.08.014. 
Appendix 1. Descriptive statistic of all the used field plots $(n=359)$.

\begin{tabular}{llllll} 
AGB $\left(\mathbf{g ~ m}^{-2}\right)$ & Total & Trees & Vascular & Mosses & Lichens \\
\hline Minimum & 0 & 5,13 & 0 & 0 & 0 \\
1st Qu. & 193,8 & 257,2 & 120,8 & 10 & 4,125 \\
Median & 448,8 & 1066 & 235 & 30,63 & 13,75 \\
Mean & 816,6 & 1305 & 290,1 & 48,62 & 22,78 \\
3rd Qu. & 934,7 & 2030 & 417,5 & 67,82 & 33,75 \\
Maximum & 5647 & 5119 & 1249 & 390,2 & 148,8
\end{tabular}

Appendix 2. Pearson correlation between the variables and their scatter plots.

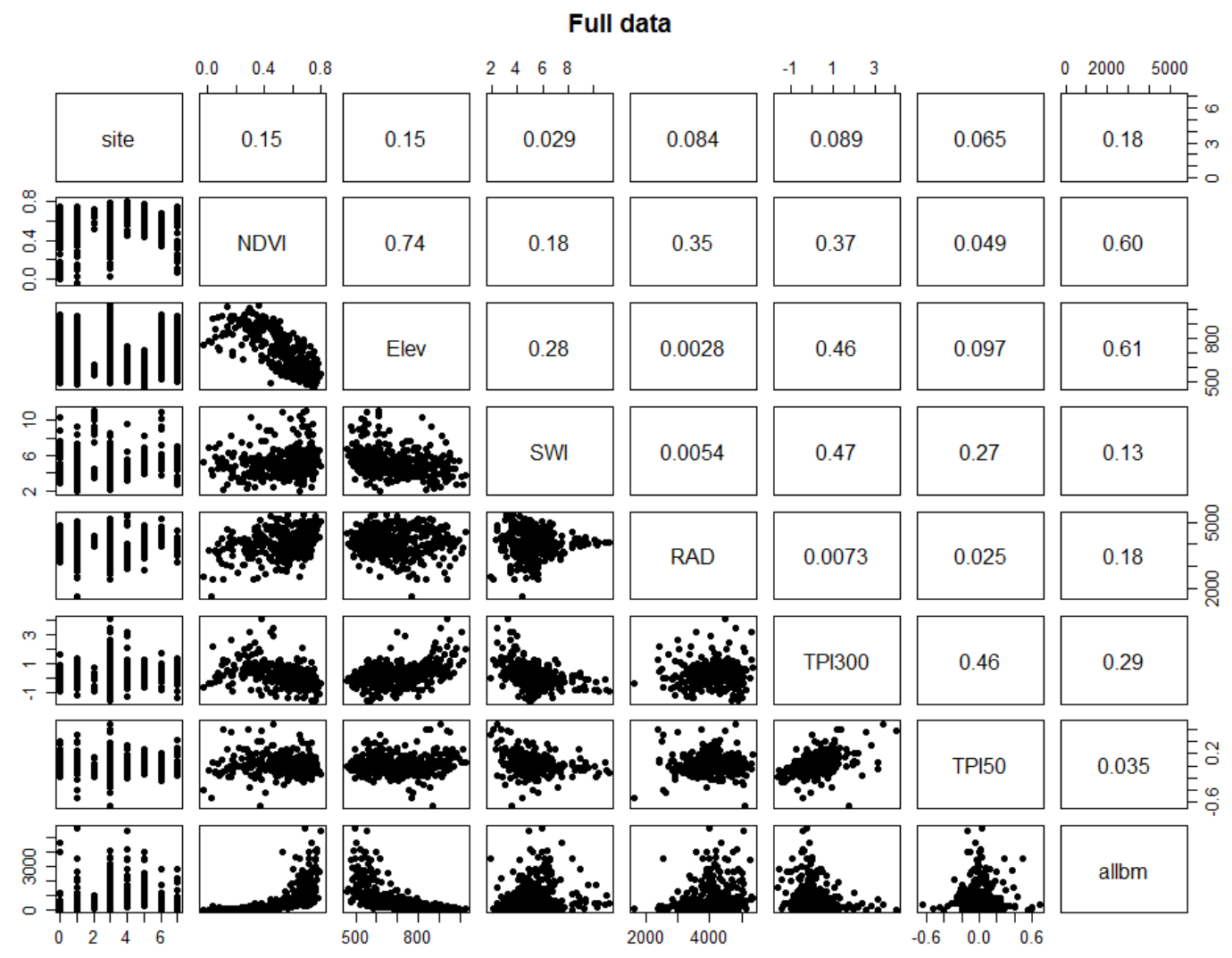




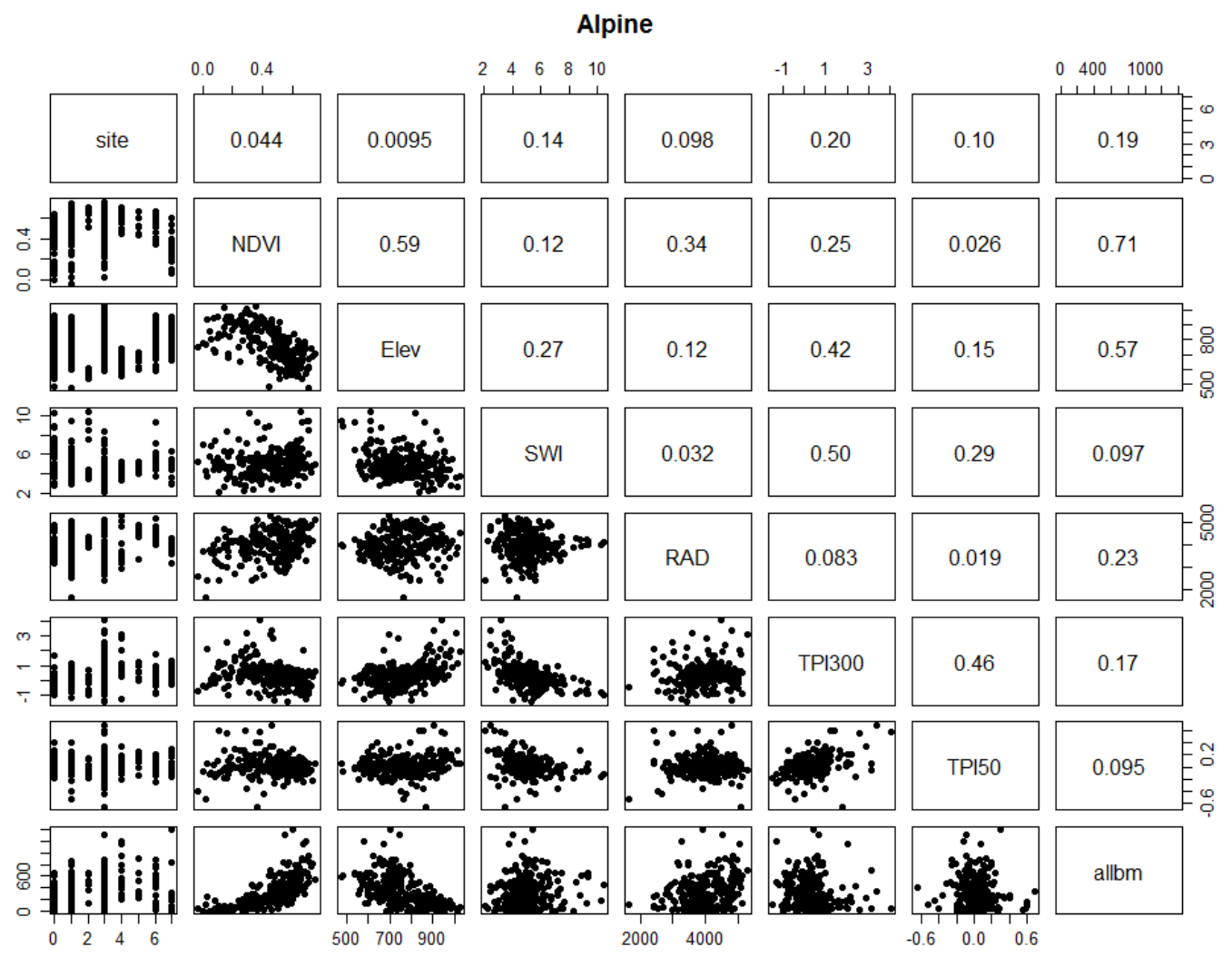

Forest

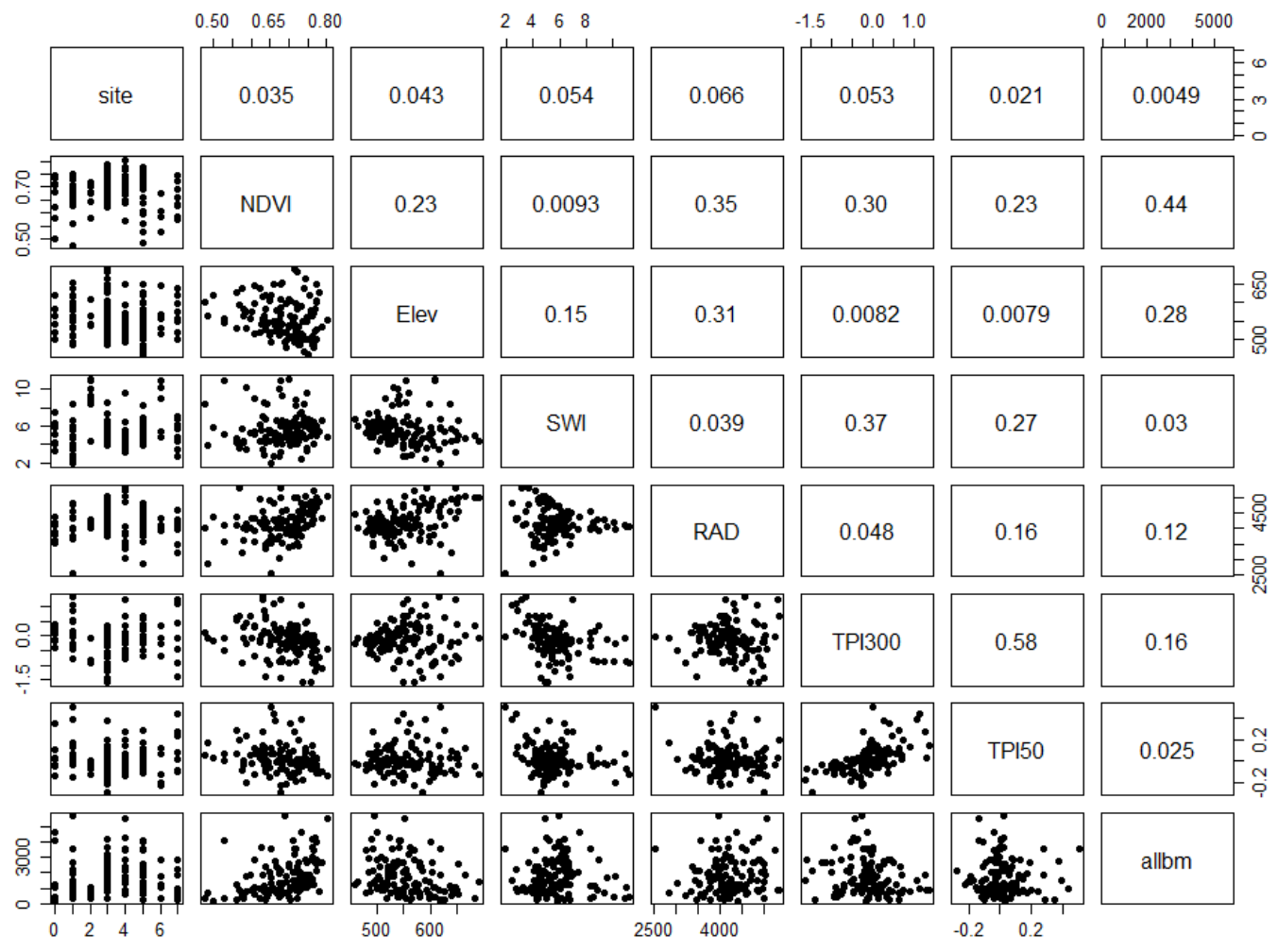

